良好な食道発声を獲得した結腸による咽喉食摘後の再建例

\author{
松崎 全成*・岡本 美孝*・横溝 道範 \\ 石川 和夫・戸川 清
}

\title{
A Case of Hypopharyngeal Cancer who Attained Good Esophageal Speech with a Pharyngoesophagus Reconstructed Using a Free Colon Graft after Pharyngo-Laryngo-Esophagectomy
}

\author{
Zensei Matsuzaki and Yoshitaka Okamoto \\ (Yamanashi Medical University) \\ Michinori Yokomizo, Kazuo Ishikawa and Kiyoshi Togawa \\ (Akita University School of Medicine)
}

\begin{abstract}
Esophageal speech in patients who undergo pharyngo-laryngo-esophagectomy is generally poorer than in those who undergo simple laryngectomy. It is particularly rare for patients undergoing reconstruction using a free jejunum graft to attain good esophageal speech. We describe hypopharyngeal cancer patient who attained good esophageal speech with a pharyngoesophagus reconstructed using a free colon graft after pharyngo-laryngo-esophagectomy. Various methods of reconstruction of the pharyngoesophagus after pharyngo-laryngo-esophagectomy are discussed in terms of postoperative swallowing function and acquisition of esophageal speech.
\end{abstract}

Key words : pharyngo-laryngo-esophagectomy, reconstruction, free colon graft, free jejunum graft, esophageal speech

\section{はじめに}

咽䐅食摘術後の咽頭・頸部食道再建に対する手術の選 択を考えた場合, 再建食道の通過性がよい, 瘦孔, 狭窄 等の合併症が少ない, 手術侵襲が少ない, といったこと はもちろん重要であるが, 発声獲得の可能性が高いこと も大事な要素である. 食道発声は生理的で清潔であり, 道具を用いずに両手を自由に使えるといらことでは今で も最もすぐれたコミュニケーション手段と考劣られる. しかし, 一般に咽喉食摘術をらけた症例が食道発声を獲 得するのは困難であり，とくに遊離空腸による咽頭食道 再建術をらけた症例が良好な食道発声を獲得することは 極めてまれである. 以前, 咽喉食摘術後の與下機能の検
討を行った結果1)から, 我々は症例に応じて, 径が太く 蠕動が少ない遊離結腸再建術を施行している。このよう な遊離結腸再建症例の中で明瞭度の良い食道発声を獲得 できた症例を経験したので，再建法の選択と併せて検討 を加兄報告する．

\section{症例}

症例 : 35歳, 男性.

主訴: 燕下痛.

既往歷，家族歴：特記すべきことなし．

現病歴：1994年10月嚥下痛出現し徐々に增強してきた ため1995年 1 月 9 日, 近医を受診、下咽頭に腫瘤を認め 
たため 1 月 10 日秋田大学耳鼻咽喉科を紹介受診となった. 初診時所見では，下咽頭右梨状窩から右披裂部にかけて 潰瘍を伴ら腫瘤が認められ，右声帯は固定していた，右 頸部に多発性に可動性不良の硬いリンパ節腫脹が認めら れた，右梨状窩の腫瘤を生検したところ中分化型扁平上 皮癌の診断であり，下咽頭癌 $\mathrm{T}_{3} \mathrm{~N}_{2 \mathrm{~b}} \mathrm{M}_{0}$ と診断した.

経過：1995年 1 月19日入院の上, 1 月23日より 3 月 8 日までCBDCA $300 \mathrm{mg}$, 5FU $3000 \mathrm{mg}$ を併用し Linac

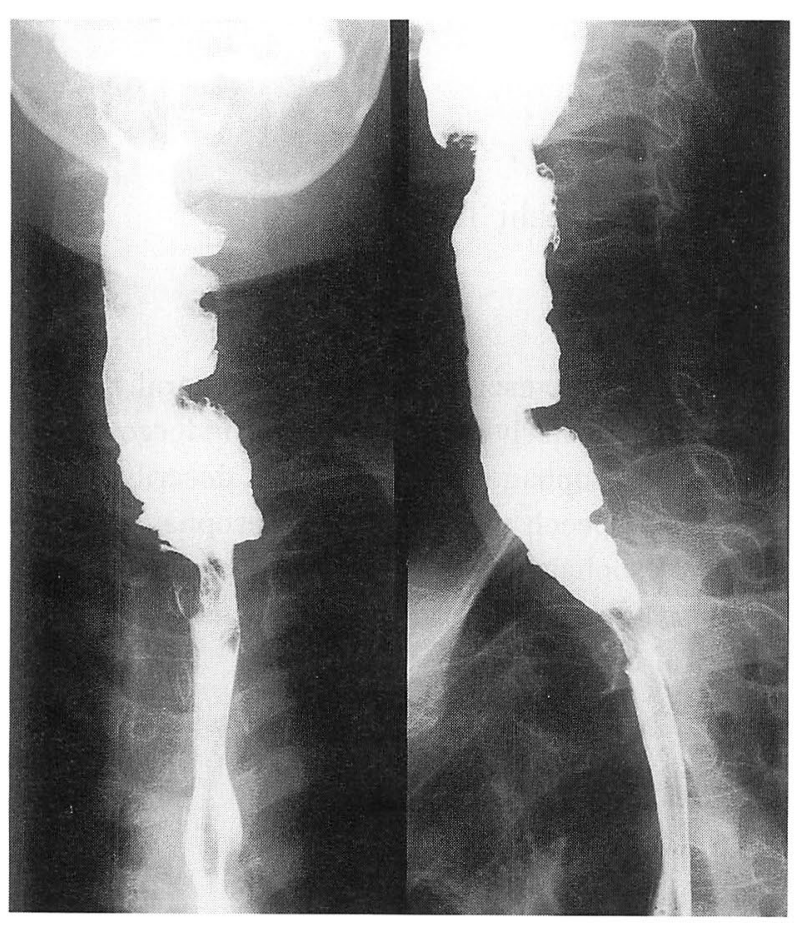

図 1 食道透視所見
60 Gy の照射療法を施行した。同年 4 月 10 日，両側頸部 郭清術, 咽頭喉頭頸部食道摘出術, 遊離結腸による再建 術を施行した。頸部郭清は右側は radical neck dissection, 左側は modified neck dissection を行った. 切除範 囲は上端は扁桃下極，下端は第一胸椎中央の高さで切除 した.

術後の食道透視では咽頭側, 食道側とも狭窄なく通過 は良好で(図 1 )蠕動運動は汪とんどなく逆流も見られな かった．摂食状況は常食を20分程で食べて扣り良好であ る.義畨は装着していない.

食道発声を空気力学的に検討すると（表 1 )FFT (fast fourier transform) 法による周波数分析で，基本周波数 $67.5 \mathrm{~Hz}$, 音圧 $66.3 \mathrm{~dB}$, 最長発声持続時間 4.0 秒, 発語 明瞭度 $54 \%$ ，小宮山 $\left.{ }^{2}\right)$ の習熟度判定法では，A（他人と の意志の眯通を行らのにあまり不自由でない)，X線透 視およびビデオによる振動部位の検討では新声門は第 5 頸椎から第 6 頸椎の高さであった．現在，再発なく，寿 司職人として社会復帰している.

\section{考察}

下咽頭・頸部食道癌の根治手術後の咽頭・頸部食道再 建には, 従来広背筋皮弁, 大胸筋皮弁, DP 皮弁等の有 茎皮弁，胃管や結腸の吊り上げ術が用いられてきたが， マイクロサージャリーの発達により近年では遊離空腸が 広く用いられるよらになってきた。咽喉食摘後の咽頭・ 頸部食道再建の選択を考えた場合，與下機能が良い，瘦 孔，狭窄等の合併症が少ない，手術侵襲が小さい，とい ったことはもちろん重要であるが，発声獲得の可能性が 高いことも大事な要素である。

表 1 症例(手術, 䀰下, 食道発声)

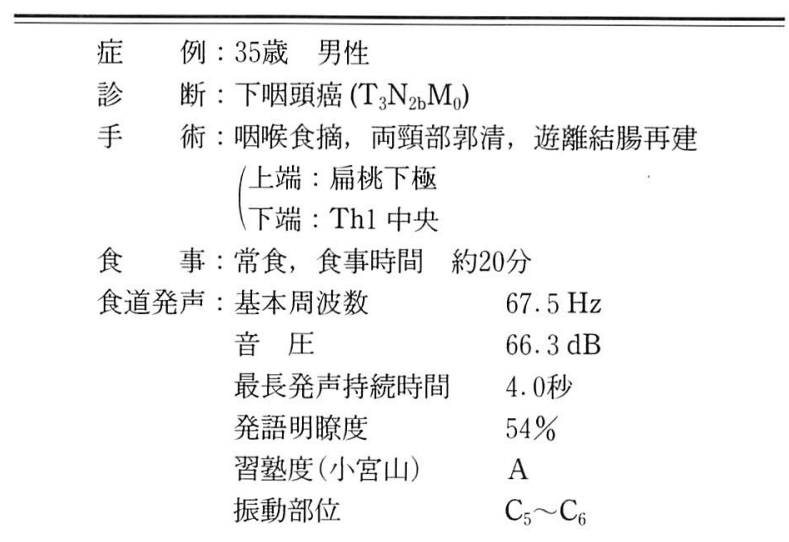


以前我々は咽喉食摘術後に咽頭・頸部食道再建術を施 行した症例を嚥下機能評価の点から検討した1)。その結 果, 有茎皮弁再建に比べ遊離空腸再建では摂食状況は良 好であったが，咽頭切除が扁桃以上に及ぶよらな咽頭高 位切除例では摂食不良例も見られた。咽頭高位切除例で は嚥下圧の低下が生じる3)ことや空腸の径の不足から咽 頭空腸吻合が容易でないこと, 空腸の蠕動運動も通過障 害に影響を与えている4) 7)ことが考えられ, それを改善 する目的で空腸の $\rho$ 型吻合による再建 ${ }^{6) 819)}$ を試みたが咽 頭空腸吻合部の通過改善には期待した効果は見られなか った。 そこで, 咽頭高位切除例の咽頭空腸吻合部を改善 する目的で, 径が太く, 蠕動運動の少ない結腸再建 ${ }^{6) 10) ~ 12) ~}$ を取り入れてきた。 その結果, 遊離結腸再建では咽頭結 腸吻合部の通過改善は期待されるが，食道切除が第 2 胸 椎レベルまで下方に及ぶと結腸食道吻合部の狭窄が生じ やすくなることが危惧された. これらのことから現在で は, 症例の切除範囲に応じて遊離結腸再建を選択してい る.

この症例もそのような結腸症例の 1 例であるが, 食道 発声の音圧, 最長発声持続時間, 発語明瞭度, 習熟度な どいずれも単純喉頭全摘術後の食道発声と比べても良好 な状態であった。食道発声は生理的で清潔である, 道具 を用いずに両手を自由に使えることにおいて今でもすぐ れたコミュニケーション手段と考えられるが，最近では， 気管と食道とにシャントを形成する tracheoesophageal shunt (TEシャント) 13) 15) も普及しており, voice prosthesisを挿入することも行われている16)17). これらは 特別な訓練を必要とせず音声獲得率も高く, 肺からの呼 気を発声のエネルギーとするため発声持続時間が長 (18)19)，といった長所がある. しかし，発声時に気管 孔を閉鎖するために片手を要すること，最近では様々な 工夫から改善されつつあるが, 食道から気管への漏れの 問題, voice prosthesisなどの器具を用いる場合にはそ の装着や洗浄が煩雑であり器具による皮膚への反応性炎 症が括こる場合がある20)，ことなどが挙げられている。 これらの問題は TEシャントに限らず, 気管・空腸瘻

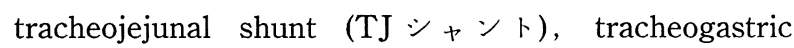
shunt (TG シャント) 21)22) でも同様である. Quer ら ${ }^{23)}$ は $\mathrm{TE}$ シャント発声と食道発声の両方が可能な喉摘者にと っては食道発声の方が有用性が高く, その70\%にプロ テーゼ除去を施行した，と報告している． TEシャント も先に述べたような利点はあるが，当科では食道発声の
長所を考え TEシャント手術は行っていない.

食道発声の獲得率は報告によって異なる。食道発声獲 得についてはこれまでX線透視による観察 24225$)$ の他に

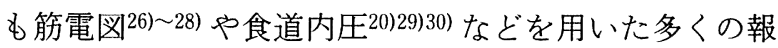
告から発声時の新声門の位置や形, 長さ, 再建咽頭腔の 広さあるいは発声時の下咽頭収縮筋の放電パターンが食 道発声の獲得と関係があったと述べられている. 一般に 咽喉食摘術をらけた症例が食道発声を獲得するのは困難 であり，とくに遊離空腸による咽頭食道再建術をらけた 症例が良好な食道発声を獲得するのは極めてまれである ことは経験的に知られている。秋田大学での症例でも咽 喉食摘後, 遊離空腸で再建し評価可能であった33例のら ち食道発声を獲得できた症例は 1 例も見られなかった。 いわゆる喉頭全摘のみの場合, 下咽頭収縮筋が新声門に 影響することは多く報告されているが，咽喉食摘術後の 遊離空腸再建では下咽頭収縮筋がないこと, 径が細く蠕 動運動があるため空気の嚥下がしにくいこと, 蠕動のた め新声門が一定した位置にできにくいことなどが食道発 声を獲得しにくい原因として考えられる．結腸は径が太 く，空腸に見られるよらな蠕動運動が少ないため(図 2) 空気の曣下に適しており, 新声門も空腸に比べ安定して いると思われる. 手術時の年齢が食道発声獲得に大きく

\section{嚥下圧測定}
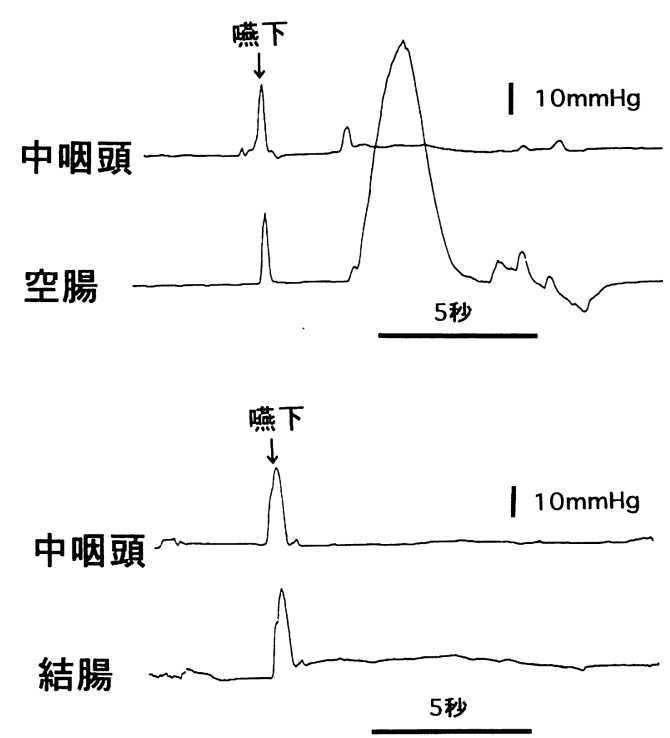

図 2 バルーン法による與下圧測定 遊離空腸再建例 (上段) と遊離結腸再建例(下段)の蠕動運 動の比較 


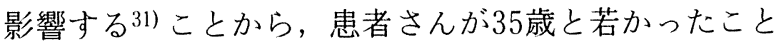
も幸いしたと思われるが，良好な食道発声を獲得できた。 患者さんはもともと寿司職人であり, 現在実際に仕事に 復鹵し寿司を握り，お客さんとも会話をし電話での応対 も可能である，仕事柄両手を使えること，衛生面での事 を考学ると食道発声ならではの長所と思われる。

食道発声の励振機構や調節機構は症例ごとに多様であ

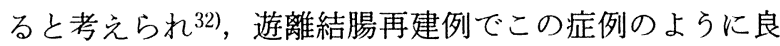
好な食道発声を獲得できた例は現在のところまだ他にい ないが，症例がまだ少ないこともあり，さらに多くの症 例の検討が必要と思われる。ただし，切除後の食道断端 と上綎隔に余裕がない場合には端々吻合では食道・結腸 吻合部の狭窄をきたす可能性もあり，吻合は径を少しで も広げるべく慎重に行う必要がある. 今後, 遊離結腸症 例を重ねていき，もし食道発声可能症例が増えてくるよ らであれば結腸再建の適応を広げることも検討すべきと 考えられた

$$
\text { まとめ }
$$

咽喉食摘後, 遊離結腸で咽頭食道を再建した症例の中 で良好な食道発声を獲得し得た 1 例を経験したので報告 した.

曣下機能, 食道発声獲得の可能性の点から咽喉食摘術 の再建法の選択について検討を加えた.

\section{参考文献}

1) 松崎全成, 岡本美孝, 横溝道範, 他 : 咽喉食摘後の再建法 についての検討. 頭頸部外科 $6: 54 \sim 60,1996$.

2 ）小宮山荘太郎：無喉頭者の発声法の選択はいかにあるべき か. 耳鼻臨床 $71: 1443 \sim 1444,1978$.

3 ) 井上要二郎, 藤田博正, 田井良明, 他 : 遊離腸管移植を用 いた下咽頭頸部食道再建後の燕下障害について。形成外科 $32: 1037 \sim 1042,1989$.

4 ）河野辰幸, 吉野邦英, 滝口 透, 他：遊離空腸移植に上る 下咽頭頸部食道再建術に和りる内圧測定から久た再建食道 の運動機能. 日気食会報 $37: 354 \sim 364,1986$.

5 ）河野辰幸, 吉野邦英, 滝口透, 他 : 遊離空腸に上る咽頭 食道再建例飞批る移植空腸自律運動の経時的变化と蟮下 障害. 日気食会報 $38: 415 \sim 421,1987$.

6 ) Osset EM, Ridocci MT, Paris F, et al : Motor activity of esophageal substitute (stomach, jejunal, and colon segments). Ann Thorac Surg $41:$ 515 519, 1986.

7 ) Meyer WC, Seigler HF, Hanks JB, et al : Postoperative function of "free" jejunal transplants for replacement of the cervical esophagus. Ann Surg 192: 439 450, 1980.

8 ）野平久仁彦, 新富芳尚, 大浦武彦, 他 : 遊離空腸移植に上 るわれわれの再建術. 日形会誌 $6: 727,1986$.

9 ）細川正夫, 田辺達三, 加藤紘之: 遊離空腸移植を用いた下 咽頭頸部食道癌再建術. 臨外 42：1807 1811, 1987.

10) Nakayama $K$, Yamamoto $K$, Tamiya $T$, et al : Experience with free autografts of the bowel with a new venus anastomosis apparatus. Surgery $55: 796 \sim 802,1964$.

11) Smith RW, Garvey CJ, Dawson PM, et al : Jejunum versus colon for free esophageal reconstruction; an experimental radiological assessment. Br J Plast Surg $40: 181 \sim 187$, 1987.

12) Flynn $M B$ and Acland $R B$ : Free intestinal autografts for reconstruction following pharyngolaryngoesophagectomy. Surg Gynecol Obstet $149:$ 858 862, 1979.

13）天津㓐郎, 松居敏夫, 牧 孝, 他: 喉摘後の音声獲得手 術一One stage で行ら新しい術式について一.日耳鼻 80： 780 785, 1977.

14）浅井良三 : 喉頭形成一㬋頭に続く一次的喉頭形成術一. 日気食会報 $33: 110 \sim 112,1982$.

15) Strome M, Mustoe TA and Kelly JH : Voice rehabilitation following laryngectomy. Arch Otolaryngol Head Neck Surg 112: 1168 1171, 1986.

16) Singer MI and Blom ED : An endoscopic technique for restoration of voice after laryngectomy. Ann Otol Rhinol Laryngol 89 : 529 533, 1980.

17) Wetmore SJ, Krueger $\mathrm{K}$, Wesson $\mathrm{K}$, et al : Long-term results of the Blom-Singer speech rehabilitation procedure. Arch Otolaryngol 11:106 109, 1985 .

18）大森孝一, 庄司和彦, 本庄 箃 : 喉頭全摘後の音声リ八ビ

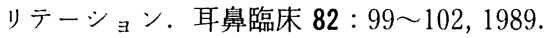

19) Amatsu M, Kinishi M, Jamir JC : Evaluation of speech of laryngectomies after the Amatsu tracheoesophageal shunt operation. Laryngoscope $94: 696 \sim 701,1984$.

20）路沢三伸：食道発声の予後と食道内压測定結果との関係. 日気食会報 $39 ： 493 \sim 506,1988$.

21）斎藤 等, 佐藤文彦, 松井隆史, 他：下咽頭頸部食道癌摘 出術後の胃管による再建と T-G シャントによる発声手術. 耳犊 $53: 1137 \sim 1142,1981$.

22) Krepsi YP, Sisson GA and Wurster CF : Voice preservation in postcricoid and cervical esophageal cancer. Arch Otolaryngol $110: 323 \sim 326,1984$.

23) Quer M, Burgures-Vila J and Garcea-Crespillo P : Primary tracheoesopharyngeal puncture vs esophageal speech. Arch Otolaryngol Head Neck Surg 118 : 188 190, 1992.

24）沢田公平：無喉頭者の発声に関する実験的研究. 耳鼻臨床 $52: 42 \sim 72,1959$.

25）小宮山荘太郎, 渡辺 宏, 笠 誠一, 他 : 食道発声の仮声 
門に関する研究. 耳鼻 $22 ： 435 \sim 441,1976$.

26）大森孝一：気管食道シャントによる発声機構. 耳鼻臨床 $85: 447 \sim 461,1992$.

27）天津睦郎：喉頭摘出後の音声再建外科. 第93回日本耳鼻咽 喉科学会総会宿題報告 : 1992 .

28) Wetmore SJ, Ryan SP, Montague JC, et al : Location of the vibratory segment in tracheoesophageal speakers. Ann Otolaryngol Head Neck Surg 93 : 355〜361, 1985.

29）有沢嘉朗：食道発声における新声門上下圧. 耳鼻臨床 補 $24: 20 \sim 37,1988$.

30）吉藤美佳, 毛利光宏, 木西 實, 他 : 気管食道発声に拈訬
る新声門の研究. 日気食会報 $45: 13 \sim 21,1994$.

31) 藤井 隆, 佐藤武男, 吉野邦俊, 他 : 喉摘者の音声リハビ リテーション, とくに食道発声習得について.日耳鼻 96 : 1086 1093, 1993.

32）西澤典子, 酒井 昇, 犬山征夫, 他 : 食道発声と TE シャ ント発声一同一被験者による比較一. 日耳鼻 $96: 1058$ 1064, 1993.

$$
\left(\begin{array}{l}
\text { 別刷請求先 : 松崎全成 } \\
\mathbf{T} 409-38 \text { 山梨県中巨摩郡玉穗町下河東1110 } \\
\text { 山梨医科大学耳鼻咽喉科学教室 }
\end{array}\right)
$$

